\title{
Vulnerability Studies of Sensitive Watershed Areas of Owerri South East Nigeria Using Digital Elevation Models
}

\author{
Ngozi AC-Chukwuocha ${ }^{1}$, Sabastine Amauche Ngah², Akajiaku C. Chukwuocha ${ }^{3}$ \\ ${ }^{1}$ Department of Environmental Technology, Federal University of Technology, Owerri, Nigeria \\ ${ }^{2}$ Institute of Geoscience and Space Technology, Rivers State University of Science and Technology, Port Harcourt, Nigeria \\ ${ }^{3}$ Department of Surveying and Geoinformatics, Federal University of Technology, Owerri, Nigeria \\ Email: *ngahsab@yahoo.com
}

How to cite this paper: AC-Chukwuocha, N., Ngah, S.A. and Chukwuocha, A.C. (2017) Vulnerability Studies of Sensitive Watershed Areas of Owerri South East Nigeria Using Digital Elevation Models. Journal of Geoscience and Environment Protection, 5, 1-10.

https://doi.org/10.4236/gep.2017.510001

Received: August 17, 2017

Accepted: October 8, 2017

Published: October 11, 2017

Copyright $\odot 2017$ by authors and Scientific Research Publishing Inc. This work is licensed under the Creative Commons Attribution International License (CC BY 4.0).

http://creativecommons.org/licenses/by/4.0/

\begin{abstract}
The impact of human activities on sensitive watershed terrains is a critical consideration in the management of urban ecosystems. Degradation of sensitive ecosystem features such as watershed land areas is often irreversible due to the extent and intensity. The vulnerability of $150 \mathrm{~m}$ watershed management zone of Otamiri river Owerri Imo State, Nigeria was studied by topographic analysis using 1977 digital elevation model (DEM), 1977 aerial photos, Shuttle Radar Topographic Mission DEM of 2000, 2012 satellite imagery and the 2016 Master Plan of the study area. The impact of human activities in elevation change was observed in the parts of substantial human activities while topographical stability was recorded for areas of very low human activities.
\end{abstract}

\section{Keywords}

Vulnerability, Watershed, Ecosystem, Impacts

\section{Introduction}

Urban ecosystem is a dynamic complex ecosystem with physical, biological and social components that interact and behave as a functional unit in any environment. Like natural ecosystem, urban ecosystems are important because they provide services such as provisioning, regulating, supporting and cultural at various scales and forms. These services are easily recognized in any given watershed area. The services such as water supply, ground water recharge, natural flood control, biodiversity conservation and micro climate regulation make watershed an environmental "sensitive area" that demands close monitoring for 
sustainable use [1].

The increasing population growth in urban ecosystem entails increase in demand for and consumption of biological and physical resources, thus causing escalating impacts on ecosystems and the services they provide. The problem posed by the growing demand for ecosystem services is compounded by the increasingly serious degradation in the capability of ecosystems to provide these services. Some of these impacts of these degradations may be irreversible as the case of biodiversity loss and soil degradation [2]. This ever-growing demands being placed on increasingly degraded ecosystems seriously diminishes the prospects for sustainable development.

Urban ecosystem management is important because of the increasing population growth and its attendant resource depletion and degradation [3]. The degradation of the ecosystem is critical if it is in the watershed land area.

The study area, Otamiri watershed is an urban watershed situated in a high density area, Owerri in Imo state, southeastern Nigeria. Imo state is one of the densely populated states in Nigeria; with Owerri having a high population density of 813.54 persons per square kilometer in the study area [4]. Otamiri River is significant because it serves as the only surface water for domestic and agricultural purposes. The watershed resources such as coarse red sands in form of laterites are used for construction purposes.

In seeking to protect the surface water in the state from ecological hazards, the 1995 Imo State Government watershed Management Regulation provides a clause that states that $150 \mathrm{~m}$ wide on both sides of the river bank, termed watershed management area should be protected and not encroached upon. Analysis on the changes in the pattern and distribution of land uses and land covers in the study area, showed that the designated $150 \mathrm{~m}$ wide watershed management zone is disturbed. Sand excavation and builtup land classes occupied $13.95 \%$ and $9.07 \%$ of the buffer zone. And $16.59 \%$ of the riparian vegetation that make up the buffer zone was converted to sand excavation site between 1977 and 2012 [5]. The high dynamicity index values of $25.78 \%$ and $11.51 \%$, (in 2006) from sand excavation sites and builtup classes respectively have implications for changes in the topography of the protected zone [6].

These inappropriate activities such as infrastructural developments, farming and sand excavation activities practiced within and around the protected watershed area, make the fragile ecosystem vulnerable to stream bank erosion, gully erosion sites at the downstream of the study area, siltation of Otamiri tributary and at the head source upstream. This paper attempts to measure changes in elevation due to human activities within the watershed management zone and along the water courses.

\section{The Study Area}

Owerri capital territory is located between latitudes $05^{\circ} 25^{\prime}$ and $05^{\circ} 32^{\prime}$ North and longitudes $06^{\circ} 57^{\prime}$ and $07^{\circ} 07^{\prime}$. Rainfall is the greatest climatic variable with an- 
nual total mean of $2190 \mathrm{~mm}$ (Imo State Govt. Ministry of Works \& Transport, 1984). The mean monthly temperature for dry season is $34^{\circ} \mathrm{C}$ and $30^{\circ} \mathrm{C}$ for rainy season. The river has average flow of $10.7 \mathrm{~m}^{3} / \mathrm{s}$ in the rainy season (SeptemberOctober) and a minimum average flow of about $3.4 \mathrm{~m}^{3} / \mathrm{s}$ in the dry season (November to February). The total annual discharge of the Otamiri is about $1.7 \times$ $10^{8} \mathrm{~m}^{3}$, and 22 percent of this $\left(3.4 \times 10^{7} \mathrm{~m}^{3}\right)$ comes from direct runoff from rainwater and constitutes the safe yield of the river [7].

According to [8], Owerri was originally an agricultural settlement of five villages with a central market linking the villages. The story of the modern Owerri may begin with the year 1901 when the British administration reached Owerri and by 1918 Owerri had become the headquarters of the Eastern Protectorate. In 1953 the Shell D'Arcy Exploration Company began to build up its headquarters known as "Shell Camp", bringing some economic growth resulting in residential expansion, market reconstruction, and a new motor park. The early plan of the town was prepared in 1948 by Tetlow, a British town planning adviser to West Africa.

On February 3, 1976, Imo State was carved out of the old East Central State, and Owerri was made the capital of the new State. Owerri has since then expanded into neighbouring towns and villages of Orji, Egbu, Mbieri, Uratta, Amakohia, Irete, Egbeada, Avu, Obinze, Nekede, Ihiagwa, Naze etc. Many layouts have been planned and developed.

From the creation of Imo State, the philosophy of the development of modern Owerri is built on the principle of a twin city. The two water bodies that transverse the present day Owerri formed the boundaries of the Old Owerri city. Otamiri River, the major water body runs approximately East-West from its source at Egbu until its confluence with the Nwaorie stream, a tributary of Otamiri River. Nwaorie runs approximately North-South down to the confluence with Otamiri River. After the Confluence, Otamiri River continues southwards to Nekede. In those early days people inhabited Owerri North of Otamiri River and East of Nwaorie Stream. There was a natural safe distance between the settlements and the water bodies. However, with the creation of Imo State came a very fast expansion of the town and human activities along the riparian forest area on the sides where humans inhabited increased tremendously also. Figure 1 shows the Owerri Master Plan, comprising of the Old Owerri and the New Owerri Twin City.

\section{Materials and Methods}

\section{Data Source and Acquisition Process}

The study employed the datasets of 1977 topographical maps (created from the same 1977 aerial photogrammetry survey of Owerri). Shuttle Radar Topographic Model DEM, tile 38 - 11 of the year 2000 series and Master plan of Owerri. The 1977 topographic maps were scanned and georeferenced to create a map mosaic of the project area. Contours and spot heights that were digitized were used to 


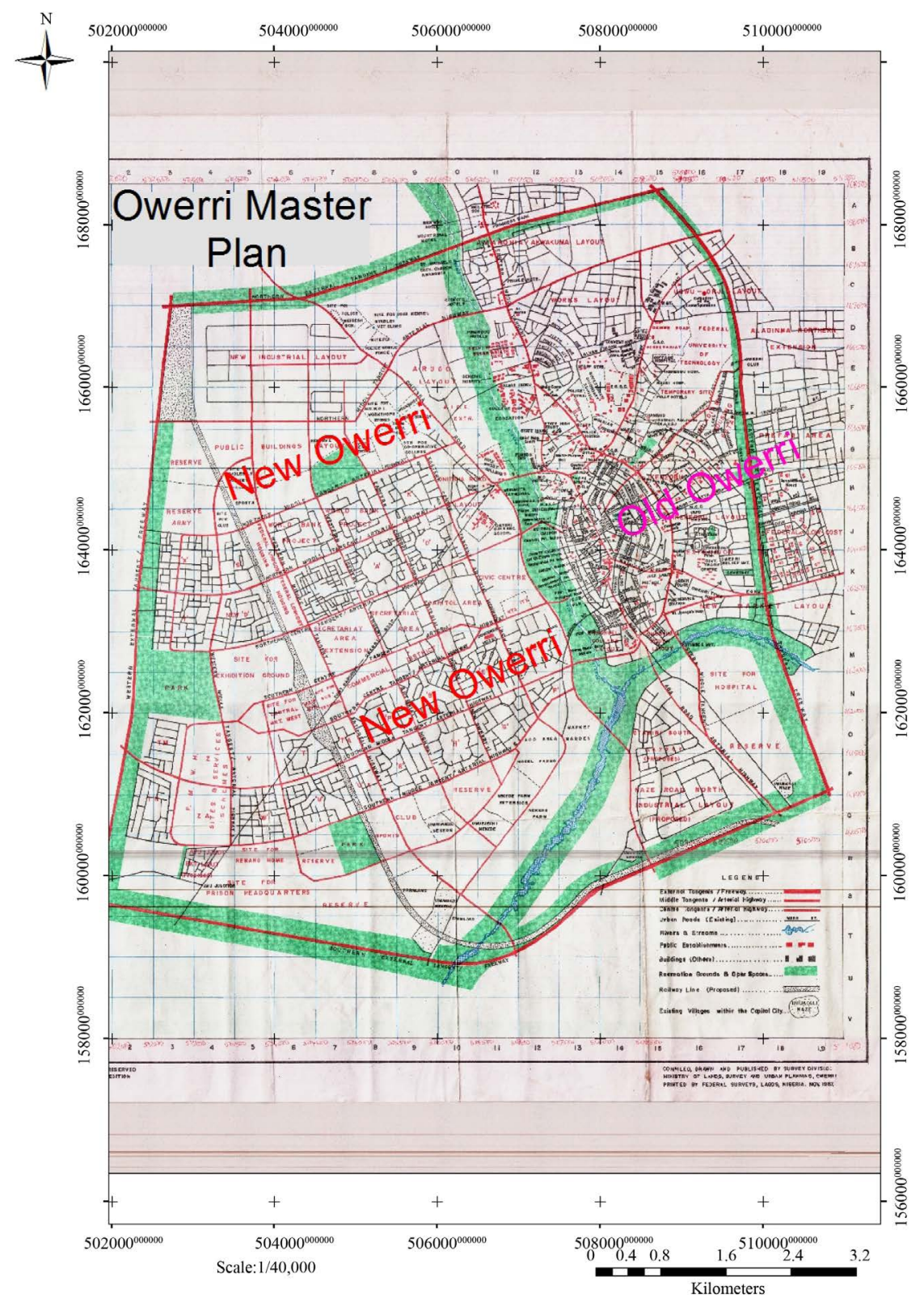

Figure 1. Owerri Master Plan showing the Old and New Owerri Twin City.

create the Digital Elevation Model of the study area. The DEM of 1977 topographic map sheets was overlaid with 2000 SRTM DEM. The result was a Digital Elevation Change Model, which was sampled at fourteen points at $1 \mathrm{~km}$ interval to determine an average value of change in parts of the water courses. In order to delineate the designated watershed management area, the Master plan of Owerri was overlaid on the change DEM of the study area.

Figure 2 shows the points along the water bodies at which elevation change data were collected. The elevation sample data points are shown as green points. Average values of elevation changes along Nworie stream, eastern Otamiri river and south of the confluence were determined to be $+5.159 \mathrm{~m},+3.616 \mathrm{~m}$ and 


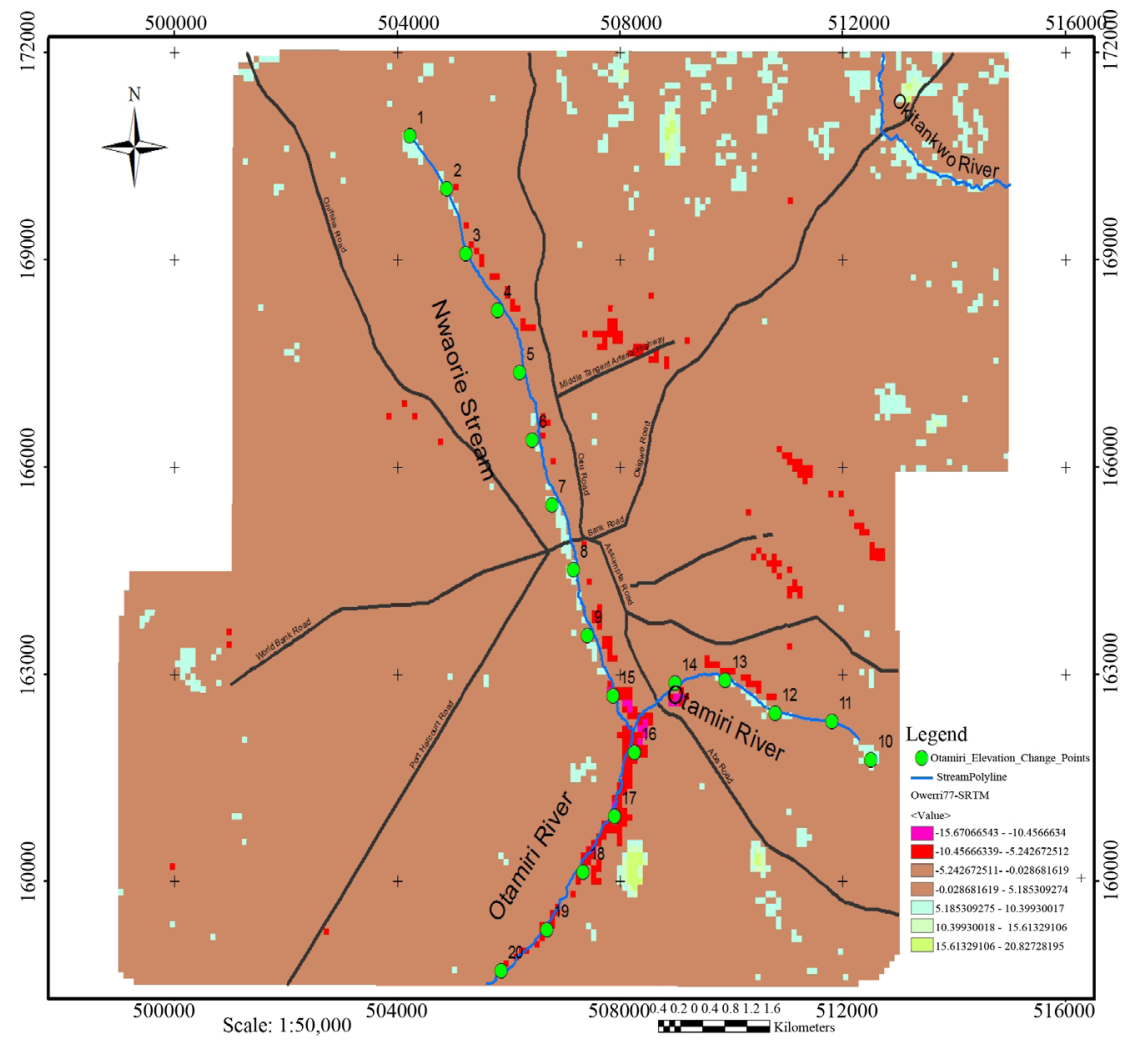

Figure 2. Sample Elevation Change Data Points along Nwaorie Stream and Otamiri.

-7.028 respectively, between 1977 and 2000. The average change values of $+5.159 \mathrm{~m},+3.616 \mathrm{~m}$ imply raised elevations along the courses of Nworie stream and eastern Otamiri river. These positive values are indicative of the sedimentation and siltation taking place along the water courses of Nwaorie stream and certain sections of Otamiri River, as may be observed physically.

$-7.028 \mathrm{~m}$ average change value of Otamiri south of the confluence implies a deeper elevation in year 2000 than in year 1977. The reduction in elevation is suggestive of erosive action taking place along Otamiri water courses south of the confluence. These areas are found within the Nekede community where gully and stream bank erosion has ravaged the land. Intensive and extensive sand and gravel excavation take place in this area. Arable farmlands were cleared and access roads built for the commercial sand excavation activities.

\section{Results and Discussion}

\section{Measures of Elevation Changes along the Water Courses}

Table 1 presents the result of average measure in the change of elevation along the water courses at average interval of $1 \mathrm{~km}$. Sample points 1 to 9 depict values of elevation changes along the course of Nwaorie stream. While sample points 10 to 14 are the values of elevation changes along the eastern Otamiri River before the confluence. And sample points 15 to 20 are values of the elevation changes south of the confluence. 
Table 1. Sample Points of Elevation Changes along Otamiri Water Courses.

\begin{tabular}{|c|c|c|c|c|}
\hline Sample Points & Easting $(\mathrm{m})$ & Northing $(\mathrm{m})$ & $\begin{array}{c}\text { Elevation Chang } \\
(\mathrm{m})\end{array}$ & $\begin{array}{l}\text { e Average Elevation Change } \\
(\mathrm{m})\end{array}$ \\
\hline 1 & 504226.15 & 170806.08 & 9.702 & \\
\hline 2 & 504888.23 & 170034.03 & 6.86 & \\
\hline 3 & 505231.83 & 169101.37 & 2.876 & \\
\hline 4 & 505795.96 & 168280.64 & 1.955 & Along Nwaorie stream \\
\hline 5 & 506200.27 & 167374.84 & 2.427 & $\begin{array}{l}\text { Course, From Source, } \\
\text { North West to }\end{array}$ \\
\hline 6 & 506420.16 & 166398.11 & 4.924 & Confluence $=+5.159 \mathrm{~m}$ \\
\hline 7 & 506772.45 & 165454.01 & 7.202 & \\
\hline 8 & 507160.21 & 164526.22 & 5.323 & \\
\hline 9 & 507415.57 & 163571.01 & 7.158 & \\
\hline 10 & 512513.20 & 161769.34 & 9.876 & \\
\hline 11 & 511813.34 & 162317.88 & 3.976 & \\
\hline 12 & 510791.92 & 162440.83 & 4.002 & $\begin{array}{l}\text { Along Otamiri River } \\
\text { Course, From Source, }\end{array}$ \\
\hline 13 & 509893.45 & 162913.71 & 1.003 & $\begin{array}{c}\text { East to } \\
\text { Confluence }=+3.616 \mathrm{~m}\end{array}$ \\
\hline 14 & 508985.52 & 162875.88 & 5.232 & \\
\hline 15 & 507878.99 & 162700.91 & -2.393 & \\
\hline 16 & 508266.75 & 161873.38 & -12.248 & \\
\hline 17 & 507907.36 & 160946.53 & -6.705 & Along Otamiri River \\
\hline 18 & 507339.91 & 160142.64 & -6.695 & $\begin{array}{c}\text { Course, From Confluence } \\
\text { Central Area }\end{array}$ \\
\hline 19 & 506687.34 & 159310.38 & -5.124 & going south $=-7.028 \mathrm{~m}$ \\
\hline 20 & 505864.53 & 158714.55 & -4.367 & \\
\hline
\end{tabular}

\section{Results and Discussion}

\subsection{Measures of Elevation Changes along the Water Courses}

Table 1 presents the result of average measure in the change of elevation along the water courses at average interval of $1 \mathrm{~km}$. Sample points 1 to 9 depict values of elevation changes along the courses of Nwaorie stream while sample points 10 to 14 are the values of elevation changes along the eastern Otamiri River before the confluence. Sample points 15 to 20 are values of the elevation changes south of the confluence.

Figure 3 is the elevation change map overlaid with the master plan of Owerri. The master plan of Owerri is dated 1977. It shows areas that were inhabitted by that year of its production, and also shows planned use of other parts of the capital city. It is observed that the areas within the sensitive water body banks that were inhabitted as at 1977 suffered worse washing away of the banks while such sensitive areas that remained unihabitted had their elevations unchanged over the period. Of course apart from the Nwaorie stream which parts of it are silting up possibly due to sand filling by government to build bridges, the other parts of the water bodies where they are silting up are the parts where the banks are 


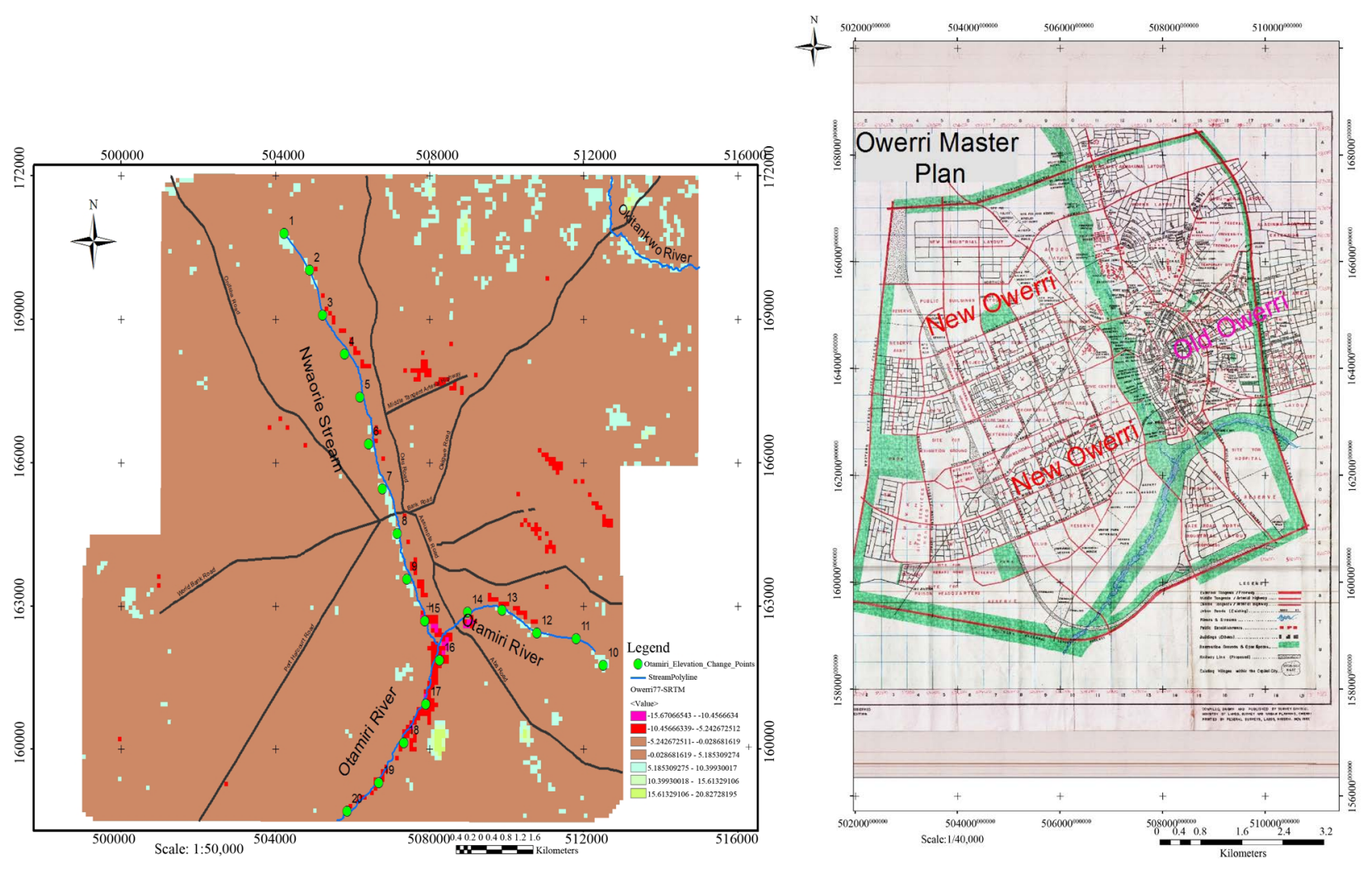

Figure 3. Otamiri Watershed Elevation Change Map compared with the Master Plan of Owerri.

washing away. These point to the harsh impact of anthropogenic activities within the sensitive watershed area.

\subsection{Elevation Changes in the Watershed Management Area}

The analyses of the elevation changes as in Table 2 for Old Owerri and Table 3 for New Owerri show marked erosion of the banks of the water bodies in the old Owerri areas which have been heavily populated over the years. The water courses along those areas, specifically along the Nwaorie Stream from the source at the North of the project area going south towards the confluence showed marked siltation up between 1977 and 2000 the border dates of the elevation data. The same is the case for Otamiri River running from East side of the project area to the confluence which has recorded remarked erosion of the bank north of the river in the old Owerri side and a marked elevation of the water bed, suggesting siltation.

Two clear behaviours were observed in the watershed management areas (river banks). The Nworie stream runs approximately in the North South direction from its source, to the confluence with Otamiri River. On the other hand Otamiri River runs approximately east to west from its source, to the confluence. The Northern river bank of Otamiri through the confluence to the eastern bank of Nworie stream fall in the old Owerri Capital city. This river bank which has been under heavy activities since the 1970s was observed to have been eroded leading 
Table 2. Elevation Changes at Sample Points in the Watershed Management Area of Old Owerri with High Human Habitation Density.

\begin{tabular}{|c|c|c|c|}
\hline Easting (m) & Northing (m) & Elev. (m) & Remarks \\
\hline 512814.54 & 161763.54 & -2.446 & \multirow{7}{*}{$\begin{array}{c}\text { North of Otamiri River Old Owerri. Densely populated area. } \\
\text { Average Elevation Change }=-4.109\end{array}$} \\
\hline 512170.34 & 162299.17 & -3.458 & \\
\hline 511960.43 & 162393.27 & -2.842 & \\
\hline 511330.71 & 162494.60 & -3.283 & \\
\hline 510614.13 & 162733.46 & -4.918 & \\
\hline 509956.46 & 163048.69 & -6.383 & \\
\hline 509593.55 & $163,182.23$ & -5.431 & \\
\hline Easting (m) & Northing (m) & Elev. (m) & \multirow{17}{*}{$\begin{array}{l}\text { East of Otamiri River, south of the confluence, Old Owerri. } \\
\text { Heavy white sand excavation site and erosion area, abutted by } \\
\text { Nekede Mechanic Village. } \\
\text { Average Elevation Change }=-7.138\end{array}$} \\
\hline 504396.47 & 170807.79 & -1.124 & \\
\hline 505058.97 & 170048.99 & -5.837 & \\
\hline 505335.07 & 169136.86 & -3.696 & \\
\hline 506031.51 & 168359.55 & -6.124 & \\
\hline 506414.22 & 167363.15 & -3.906 & \\
\hline 506680.52 & 166439.42 & -4.631 & \\
\hline 507055.64 & 165491.85 & -1.152 & \\
\hline 507328.00 & 164544.75 & -4.018 & \\
\hline 507630.01 & 163624.49 & -3.778 & \\
\hline 508045.03 & 162756.39 & -10.272 & \\
\hline Easting (m) & Northing (m) & Elev. (m) & \\
\hline 509104.60 & 162689.14 & -14.667 & \\
\hline 508455.62 & 161840.47 & -6.593 & \\
\hline 508074.97 & 160823.32 & -5.818 & \\
\hline 507625.67 & 160030.82 & -5.249 & \\
\hline 506858.13 & 159175.91 & -3.361 & \\
\hline
\end{tabular}

to reduction in elevation of the river banks by an average $4.454 \mathrm{~m}$ for east of Nworie and $4.108 \mathrm{~m}$ for North of Otamiri.

The southern bank of Otamiri from its source to the confluence has been largely uninhabited and untampered. The water bank west of Nworie stream down to the confluence and further down south along the western bank of Otamiri river from the confluence going towards Nekede, a village close to the capital city fall in the New Owerri Capital Territory, an area largely uninhabited over the years. These water banks were observed not to have been eroded, in some cases recording average elevation change ranging from $0.000 \mathrm{~m}$ to $0.048 \mathrm{~m}$ indicating no change in elevation.

These average changes in elevation reported along the water courses and within the designated buffer zone have strong implications for the ecosystem and its resources. The ecosystem is vulnerable to severe decline in abundance of specie 
Table 3. Elevation Changes at Sample Points in the Watershed Management Area of New Owerri with Low Density Human Activities.

\begin{tabular}{|c|c|c|c|}
\hline Easting (m) & Northing (m) & Elev. (m) & REMARKS \\
\hline 504052.11 & 170791.67 & 0.414 & \multirow{9}{*}{$\begin{array}{l}\text { West of Nwaorie Stream, New Owerri. Very } \\
\text { Sparsely populated area. Average Elevation Change } \\
\qquad=-0.000\end{array}$} \\
\hline 504690.95 & 169895.24 & -0.124 & \\
\hline 504948.54 & 169055.49 & -0.289 & \\
\hline 505479.18 & 168200.28 & -0.186 & \\
\hline 504964.00 & 169034.88 & -0.288 & \\
\hline 506081.95 & 166299.23 & -0.004 & \\
\hline 506349.85 & 165356.44 & 0.022 & \\
\hline 506787.76 & 164449.71 & 0.624 & \\
\hline 507081.42 & 163594.50 & -0.171 & \\
\hline Easting (m) & Northing (m) & Elev. (m) & \multirow{5}{*}{$\begin{array}{l}\text { South of Otamiri Stream. New Owerri. Very } \\
\text { Sparsely populated area. Average Elevation Change } \\
=-0.022\end{array}$} \\
\hline 511769.16 & 162208.64 & 0.146 & \\
\hline 510677.13 & 162227.36 & 0.216 & \\
\hline 510764.49 & 162214.88 & -0.216 & \\
\hline 509734.86 & 162776.50 & -0.235 & \\
\hline Easting (m) & Northing (m) & Elev. (m) & \multirow{6}{*}{$\begin{array}{l}\text { West of Otamiri River. New Owerri. Very Sparse } \\
\text { human activities in this area. Average Elevation } \\
\text { Change }=0.048\end{array}$} \\
\hline 507715.10 & 162033.48 & -0.196 & \\
\hline 507349.32 & 161028.86 & -0.067 & \\
\hline 506880.50 & 160307.60 & 0.155 & \\
\hline 506221.06 & 159565.73 & 0.270 & \\
\hline 505489.49 & 158901.14 & 0.077 & \\
\hline
\end{tabular}

along the riparian vegetation corridors of the river banks. And with the current spate of city development, encroaching into the buffer zone, there may be a near loss of biodiversity from the watershed ecosystem. Loss of biodiversity has been noted as one of irreversible human impact on the ecosystem [2]. The ecosystem is prone to greater risk of climate change, because of their weak capacity for resilience.

\section{Conclusions and Recommendations}

\subsection{Conclusions}

This study has effectively demonstrated the feasibility of the "Vulnerability Studies of Sensitive Watershed Areas by human activities in Owerri South East Nigeria Using Digital Elevation Models (DEM)”. Digital Elevation Models (DEM) of 1977 and 2000 epochs were processed on a Geographic Information Systems (GSI) platform to create the digital elevation change matrix which is a Raster data type showing recorded changes in elevation over the period of study.

These studies derived foundational scaled quantities of the impact of human 
activities on the sensitive parts of the watershed. Based on the above findings, the study concludes that the $150 \mathrm{~m}$ wide on both sides of the river banks designated as watershed management zone is threatened with degradation due to intensive human impacts. The loss in ecosystem services is loss of biodiversity and arable land, increase in impervious surfaces with its attendant overland flow, loss of properties and human settlements and increase in the treatment of the water for domestic and industrial needs.

\subsection{Recommendations}

Based on the findings it is recommended that these digital elevation change matrix method be employed in the scaled studies of the vulnerability of the sensitive watershed areas. These studies can actually lead to the determination of what volume of sand that has been washed away and through that ultimately the population of earth inhabiting faunas that have been washed away with the sand. A number of other impacts could be studied using this method.

By the conclusion of these vulnerability studies, it is obvious that the Otamiri River and the attendant ecosystem are threatened and may silt up. Government is called upon for immediate intervention to stop further constructions within the $150 \mathrm{~m}$ protected area and to also reduce human activities that would impact the Otamiri watershed and ecosystem negatively.

\section{References}

[1] Revenga, C., Murray, S., Abramovitz, J., and Hammond, A., (1998) Watersheds of the World: Ecological Value and Vulnerability. World Resource Institute, Washington DC.

[2] Lambin, E.F. and Geist, H.J. (2010) Land Use and Land Cover Change: Local Processes and Global Impacts. IGBP Global Change, The IGBP Series, International Geosphere-Biosphere Program, Human Dimensions Global Environment Change Program. Berlin Heidelberg, Springer.

[3] Jing, S., Hongwei, L., Yang, Z. and Li, H. (2016) Vulnerability Assessment of Urban Ecosystems Driven by Water Resources, Human Health and Atmospheric Environment. Journal of Hydrology, 536, 456-470.

[4] Federal Republic of Nigeria (2009) Federal Republic of Nigeria Official Gazette: Supplement to the Gazette, Government Notice No.2. FGP 16122009/10,000(0L020) Federal Government Printer, Abuja, 96.

[5] Chukwuocha, A.C. and Igbokwe, J.I. (2014) Delineation and Characterization of Sub-Catchments of Owerri, South East Nigeria, Using GIS. American Journal of Geographic Information System, 3, 1-9.

[6] AC-Chukwuocha, N.B. (2015) Analysis of Structural Changes in Land Use and Land Cover of Otamiri Watershed in Owerri, South East Nigeria. Journal of Environment and Earth Science, 5, 51-59.

[7] Egboka, B.C., and Uma, K.O. (1985) Water Resources of Owerri and Its Environs, Imo State. Nigeria Journal of Mineral Geology, 22, 57-64.

[8] Fingerhuth and Partners (1977) Imo State Capital Owerri, Master Plan Report Phase II. Felderggstrasse, Zurich. 